\title{
Prevention of sudden cardiac death in childhood-onset hypertrophic cardiomyopathy
}

Juan Pablo Kaski, Gabrielle Norrish

Centre for Inherited Cardiovascular Diseases, Great Ormond Street Hospital, London UK

Institute of Cardiovascular Sciences University College London, UK

\section{Address for correspondence}

A/Prof Juan Pablo Kaski MD(Res) FESC FRCP

Centre for Inherited Cardiovascular Diseases, UCL Institute of Cardiovascular Science

and Great Ormond Street Hospital, London, WC1N 1DZ

Email: j.kaski@ucl.ac.uk

Fax no: $+44(0) 2077626727$

Telephone no: $+44(0) 2078298839$ 


\begin{abstract}
Sudden cardiac death (SCD) is the most common cause of death in children with HCM. Although recent population-based studies have shown that SCD rates are lower than previously thought, it still occurs more frequently than in adult patients, highlighting the importance of accurate identification of those at risk. The traditional approach to risk prediction in childhood-onset HCM, using cumulative risk factor thresholds and adopted by current international guidelines, has involved extrapolation of adult data, but recent evidence has demonstrated that this approach does not accurately discriminate high-risk from low-risk individuals. In response to this knowledge gap, novel paediatric-specific risk stratification models have been developed that allow calculation of individualised estimates of SCD risk and enable a personalised and shared decision-making approach to ICD implantation.
\end{abstract}




\section{Introduction}

Hypertrophic cardiomyopathy (HCM), defined as left ventricular hypertrophy (LVH) in the absence of abnormal loading conditions ${ }^{1}$, has an estimated population prevalence in childhood of approximately 3 per $100,000^{2}$ and an annual incidence of less than $0.5 / 100,000^{2-4}$. Although the underlying aetiology, particularly in childhood, is heterogeneous, including malformation syndromes (e.g. Noonan syndrome and related disorders), inborn errors of metabolism (e.g. Pompe disease and storage disorders), and neuromuscular disease (e.g. Friedreich ataxia), most cases, even in very young children, are caused by variants in one or more cardiac sarcomere protein genes ${ }^{5-9}$. Age at presentation and aetiology are major determinants of natural history and overall outcome; children with non-syndromic HCM generally have a good prognosis (estimated 5-year survival above 80\%) but those with metabolic or malformation syndromes, and those presenting with heart failure symptoms in infancy (in the first year of life) have substantially poorer outcomes $5,7,8$. Beyond infancy, sudden cardiac death (SCD) is the most common cause of death during childhood and adolescence ${ }^{5,10}$ and identifying those individuals with HCM at highest risk of SCD is a major aspect of clinical care in specialist paediatric HCM centres.

\section{Pathophysiology of SCD in HCM}

Hypertrophic cardiomyopathy is characterised histologically by the presence of myocyte disarray, interstitial fibrosis and small vessel disease. These features are thought to act as a substrate for ventricular arrhythmia, and the extent of myocyte disarray has been associated with SCD at post-mortem evaluation ${ }^{11}$. The pathophysiological mechanisms leading to the generation of malignant arrhythmias are likely multifactorial, and include dispersion of repolarisation caused by LVH; disruption of cell alignment due to myocte disarray; and localised conduction block and altered calcium sensitivity related to fibrosis ${ }^{12}$, 13. This combination of structural and biochemical abnormalities would be expected to result in an almost universal incidence of ventricular arrhythmia; the fact that the overall incidence of SCD in HCM is relatively low suggests that additional transient electrical (e.g. premature ventricular ectopy or atrial arrhythmias) or structural changes (e.g. myocardial ischaemia) are required to trigger malignant ventricular arrhythmias and SCD. 


\section{Preventing SCD in childhood HCM}

Early studies in small, highly selected childhood cohorts reported an annual incidence of SCD of up to $7 \%{ }^{14,15}$, leading to HCM being considered a highly malignant disease in children. The advent of data from larger, more representative population-based studies has shown SCD rates between 0.8-2\% per year ${ }^{10,16,17}$, much lower than the initial reports but nevertheless substantially higher than those seen in adults with $\operatorname{HCM}(<0.8 \%),{ }^{18,19}$. Recent longitudinal datasets from the Sarcomeric Human Cardiomyopathy Registry (SHaRE) have demonstrated that in childhood-onset HCM patients, arrhythmic events are responsible for more than $50 \%$ of adverse events occurring within 10 years of diagnosis, with a cumulative incidence of $8.8 \%$, and that children with $\mathrm{HCM}$ are $36 \%$ more likely to experience an arrhythmic event during follow up compared to those diagnosed in adulthood ${ }^{10}$.

Although high dose beta-blockade has been reported to reduce the risk of SCD in a small single-centre study ${ }^{20}$, this has not been independently confirmed in other paediatric populations and there is no convincing evidence that pharmacological therapy alone can prebvent sudden cardiac death. The mainstay of preventative therapy, therefore, is the implantable cardioverter-defibrillator (ICD), which has been shown to be effective at terminating malignant ventricular arrhythmias in both children and adults with $\mathrm{HCM}^{21,22}$. However, compared to adults, ICD implantation in children is associated an increased risk of device-related complications (including lead fracture or migration, infective endocarditis or venous occlusion) and inappropriate therapies. Data from retrospective population studies suggest that ICD-related complications occur in up to $30 \%$ of childhood cohorts over a relatively short follow-up time (mean 5-7 years) ${ }^{22}$, 23. Previous childhood ICD studies have raised concerns regarding high rates of inappropriate therapies ${ }^{21,22,24,25}$, but recent data from a national cohort study of children with HCM and an ICD from the United Kingdom (UK) suggest that, with current $t$ management strategies, this risk may not be as high as previously thought and is comparable to that reported in adults $(\approx 8 \%)^{23,26}$. Nevertheless, it is clear that, as children with an ICD will have a lifelong exposure to these risks and no device or programming strategies have been identified to reduce this risk ${ }^{23}$, accurate identification of those children at highest risk who would benefit most from ICD implantation while minimising the risk of complications is essential. 


\section{Identifying those at risk}

Implantation of a secondary prevention ICD in children who have previously experienced a sustained malignant arrhythmia is a class I indication in European and North American guidelines $^{1,27}$ and recent data from the UK have shown that almost two thirds of patients undergoing secondary prevention ICD implantation received an appropriate ICD therapy for a ventricular tachyarrhythmia within 5 years of follow up ${ }^{23}$. Identifying those patients who have not yet had a sustained ventricular arrhythmia but are at risk of SCD, however, is more challenging. Until recently, data on clinical risk factors for SCD events in childhood-onset HCM were scarce and largely extrapolated from adult cohorts. In 2017, we performed the first systematic review and meta-analysis of risk factors in children with HCM, identifying four major risk factors associated with SCD events in two or more univariable analyses (table 1): previous VF or sustained VT; unexplained syncope; nonsustained ventricular tachycardia (NSVT); and extreme LVH (defined as a LV maximal wall thickness $\geq 30 \mathrm{~mm}$ or Z score $\geq 6)^{28}$. The number of studies available for inclusion in this meta-analysis was small $(n=23)$ and individual studies reported small and heterogeneous cohorts, but suggested important differences between adult and paediatric risk factors. In particular, there was insufficient evidence to consider a family history of SCD as a risk factor in children with $\mathrm{HCM}$, possibly related to a higher prevalence of de novo variants in childhood HCM; the inclusion of non-sarcomeric disease; under-reporting of family history in paediatric cohorts; or the fact that follow-up times in paediatric studies tend to be relatively short and children with HCM may not express their full phenotype until they reach adult age.

\section{Current risk stratification recommendations in childhood HCM}

Current guidelines from the European Society of Cardiology (ESC) and the American Heart Association/American College of Cardiology (AHA/ACC) use a cumulative risk factor approach to recommend ICD implantation in children with HCM ( $\geq 1$ risk factor in the AHA/ACC guideline ${ }^{27}$ and $\geq 2$ risk factors in the ESC guidelines ${ }^{1}$, as class II indications). This approach is based on clinical risk factors largely extrapolated from adult practice (extreme LVH, unexplained syncope, NSVT and family history of SCD) $)^{1,27}$ and provides relative rather than absolute estimates of risk. However, the only study to externally validate this approach 
showed that it has only modest discriminatory ability [c-statistic 0.62 (95\% Cl 0.55-0.70)], leading to unnecessary ICD implantation in many children ${ }^{29}$. The 2020 AHA/ACC guidelines suggest that additional risk factors, including the presence of LGE on CMRI and LV systolic function, may help to improve the performance of the current recommendations, but this has not been evaluated in children.

\section{A new individualised approach to SCD risk stratification in childhood HCM}

In response to the lack of paediatric-specific evidence and the limited ability of current guidelines to accurately discriminate between high and low risk patients, a large multicentre international collaboration was established (the International Paediatric Hypertrophic Cardiomyopathy Consortium - IPHCC) to develop a more personalised approach to risk stratification for children with $\mathrm{HCM}$, mimicking the move towards individualised risk prediction in adult HCM. The HCM Risk-SCD model, adopted by the ESC HCM guidelines, uses readily available clinical risk factors to calculate individualised estimated for 5-year SCD risk to guide ICD implantation, but crucially is not validated for use in in children $<16$ years of age ${ }^{19}$. External validation of the HCM Risk-SCD model in IPHCC cohort showed it to have poor correlation between predicted and observed risk, underestimating for all risk groups, confirming that should not be used in childhood HCM patients ${ }^{16}$. In 2019, the first validated paediatric-specific risk model for SCD was developed (HCM Risk-Kids), based on data from 1024 children with non-syndromic HCM from the IPHCC ${ }^{16}$. This new paediatric model uses 5 readily available clinical predictors assessed at the time of baseline clinical evaluation, selected a priori from the published literature (MLVWT Z score, LA Z score, LVOT gradient, NSVT and unexplained syncope), to calculate personalised estimates of 5-year SCD risk. Internal validation of HCM Risk-Kids showed it to have superior discriminatory ability than the current international guidelines, with good calibration between the expected and observed risk (Figure 1), and an overall performance similar to that reported for the adult HCM Risk-SCD model (C-Index 0.69 vs 0.70$)^{30}$. External validation of HCM Risk-Kids has been completed (currently under review) and the model is available online (https://hcmriskkids.org), allowing clinicians to calculate individualised estimates of risk for the first time. 
Following the publication of HCM Risk-Kids, an alternative paediatric specific risk model (PRIMaCY) was developed using a largely North American cohort $(n=572)^{17}$ and externally validated in a small cohort of 285 patients from the SHaRe consortium. Performance of the model was superior to current guidelines and similar to the HCM Risk-Kids model (C-statistic 0.707). Despite differences in risk factor selection approaches, the clinical parameters included in PRIMaCY are very similar to those in HCM Risk-Kids, with the exception that PRIMaCY includes two measures of LVH (septal and posterior wall thickness, rather than MLVWT) and age as independent predictors (table 2). Age was not included in the HCM Risk-Kids model as its role in prognosis remains unclear beyond infancy ${ }^{10,31}$ and its inclusion in post-hoc did not improve its performance. It is likely, however, that any effect of age on risk may accounted for by the use of body surface area-corrected (rather than absolute) echocardiographic measurements.

\section{Knowledge gaps}

The development of paediatric-specific individualised risk prediction models represents a significant advance in the management of childhood HCM. Although superior to current paediatric risk stratification guidelines, it is likely that their performance can be refined by the inclusion of additional risk factors. Late gadolinium enhancement (LGE) on cardiac magnetic resonance imaging (CMR) has been shown to be an independent risk factor for SCD in adults with $\mathrm{HCM}^{32}$. Data in children are limited, but recent studies have suggested that LGE is associated with the degree of LVH and correlates with disease progression ${ }^{33,34}$. Its role as an independent risk factor has not been established, but a recent single centre study has reported improved discriminatory performance of both the current guidelines and the HCM Risk-Kids model with the addition of LGE as either a binary or continuous variable ${ }^{35}$. Future multi-centre studies are required to investigate the role of LGE in paediatric risk stratification.

In contrast, a recent study from the IPHCC cohort did not show an improvement in the performance of the HCM Risk-Kids model with the addition of individual and combined electrocardiographic (ECG) parameters, suggesting a limited role for the ECG in risk stratification in childhood $\mathrm{HCM}^{36}$. 
The role of genotype in risk stratification for childhood HCM remains unclear, and recent data from the SHaRE registry did not find a higher lifetime risk of arrhythmic events for genotype positive children with HCM compared to those without a genetic variant identified ${ }^{10}$. Furthermore, inclusion of genotype in the PRIMaCY model did not significantly improve its performance ${ }^{17}$. It is likely that as yet unidentified genetic and epigenetic modifiers play a role in the expression of sarcomere protein gene variants and a variantspecific approach, including assessment of the contribution of common genetic variants, is likely to be needed ${ }^{37}$. This will require further multicentre collaborative efforts.

Finally, there are very little data on risk stratification in patients with syndromic disease. Current risk stratification algorithms and models, including HCM Risk-Kids and PRIMaCY, exclude patients with RASopathy syndromes and metabolic $\mathrm{HCM}$, and whether these are applicable to nonsyndromic disease has not yet been evaluated, in part related to the relative rarity of these aetiologies, but also because SCD has been reported infrequently in this context. However, there are data emerging to suggest that SCD can occur in children and teenagers with RASopathy syndromes and inborn errors of metabolism ${ }^{5}$. The limited available suggest that the degree of LVH may be a strong predictor of SCD in patients with RASopathy syndromes ${ }^{38}$, but future studies will need to determine if risk stratification methods developed for non-syndromic disease can be extrapolated to syndromic patients and to identify disease-specific risk factors.

\section{Conclusions}

SCD is the most common cause of death in childhood HCM and occurs more frequently than in adult patients. Recently developed paediatric-specific risk prediction models allow clinicians to calculate individualised estimates of 5-year risk and are an important novel tool for shared decision making in relation to ICD implantation. Future studies are required to provide real world validation and to further refine risk stratification for SCD in children with HCM in the current era of personalised medicine. 


\section{References}

1. Elliott PM, Anastasakis A, Borger MA, Borggrefe M, Cecchi F, Charron P, Hagege AA, Lafont A, Limongelli G, Mahrholdt H, McKenna WJ, Mogensen J, Nihoyannopoulos $P$, Nistri $S$, Pieper PG, Pieske B, Rapezzi C, Rutten FH, Tillmanns C, Watkins H. 2014 ESC Guidelines on diagnosis and management of hypertrophic cardiomyopathy: the Task Force for the Diagnosis and Management of Hypertrophic Cardiomyopathy of the European Society of Cardiology (ESC). Eur Heart J 2014;35(39):2733-79.

2. Arola A, Jokinen E, Ruuskanen O, Saraste M, Pesonen E, Kuusela AL, Tikanoja T, Paavilainen T, Simell O. Epidemiology of idiopathic cardiomyopathies in children and adolescents. A nationwide study in Finland. Am J Epidemiol 1997;146(5):385-93.

3. Nugent AW, Daubeney PE, Chondros P, Carlin JB, Cheung M, Wilkinson LC, Davis AM, Kahler SG, Chow CW, Wilkinson JL, Weintraub RG. The epidemiology of childhood cardiomyopathy in Australia. N Engl J Med 2003;348(17):1639-46.

4. Lipshultz SE, Sleeper LA, Towbin JA, Lowe AM, Orav EJ, Cox GF, Lurie PR, McCoy KL, McDonald MA, Messere JE, Colan SD. The incidence of pediatric cardiomyopathy in two regions of the United States. N Engl J Med 2003;348(17):1647-55.

5. Norrish G, Field E, McLeod K, Ilina M, Stuart G, Bhole V, Uzun O, Brown E, Daubeney PEF, Lota A, Linter K, Mathur S, Bharucha T, Kok KL, Adwani S, Jones CB, Reinhardt Z, Kaski JP. Clinical presentation and survival of childhood hypertrophic cardiomyopathy: a retrospective study in United Kingdom. Eur Heart J 2019;40(12):986-993.

6. Kaski JP, Syrris P, Esteban MT, Jenkins S, Pantazis A, Deanfield JE, McKenna WJ, Elliott PM. Prevalence of sarcomere protein gene mutations in preadolescent children with hypertrophic cardiomyopathy. Circ Cardiovasc Genet 2009;2(5):436-41.

7. Nugent AW, Daubeney PE, Chondros P, Carlin JB, Colan SD, Cheung M, Davis AM, Chow CW, Weintraub RG. Clinical features and outcomes of childhood hypertrophic cardiomyopathy: results from a national population-based study. Circulation 2005;112(9):1332-8.

8. Colan SD, Lipshultz SE, Lowe AM, Sleeper LA, Messere J, Cox GF, Lurie PR, Orav EJ, Towbin JA. Epidemiology and cause-specific outcome of hypertrophic cardiomyopathy in children: findings from the Pediatric Cardiomyopathy Registry. Circulation 2007;115(6):77381. 
9. Morita $\mathrm{H}$, Rehm HL, Menesses A, McDonough B, Roberts AE, Kucherlapati R, Towbin JA, Seidman JG, Seidman CE. Shared genetic causes of cardiac hypertrophy in children and adults. N Engl J Med 2008;358(18):1899-908.

10. Marston NA, Han L, Olivotto I, Day SM, Ashley EA, Michels M, Pereira AC, Ingles J, Semsarian C, Jacoby D, Colan SD, Rossano JW, Wittekind SG, Ware JS, Saberi S, Helms AS, Ho $\mathrm{CY}$. Clinical characteristics and outcomes in childhood-onset hypertrophic cardiomyopathy. Eur Heart J 2021.

11. Varnava AM, Elliott PM, Mahon N, Davies MJ, McKenna WJ. Relation between myocyte disarray and outcome in hypertrophic cardiomyopathy. Am J Cardiol 2001;88(3):275-9.

12. Wang L, Kim K, Parikh S, Cadar AG, Bersell KR, He H, Pinto JR, Kryshtal DO, Knollmann $B C$. Hypertrophic cardiomyopathy-linked mutation in troponin T causes myofibrillar disarray and pro-arrhythmic action potential changes in human iPSC cardiomyocytes. J Mol Cell Cardiol 2018;114:320-327.

13. Saumarez RC, Heald S, Gill J, Slade AK, de Belder M, Walczak F, Rowland E, Ward DE, Camm AJ. Primary ventricular fibrillation is associated with increased paced right ventricular electrogram fractionation. Circulation 1995;92(9):2565-71.

14. McKenna WJ, Franklin RC, Nihoyannopoulos P, Robinson KC, Deanfield JE. Arrhythmia and prognosis in infants, children and adolescents with hypertrophic cardiomyopathy. J Am Coll Cardiol 1988;11(1):147-53.

15. McKenna WJ, Deanfield JE. Hypertrophic cardiomyopathy: an important cause of sudden death. Arch Dis Child 1984;59(10):971-5.

16. Norrish G, Ding T, Field E, Ziolkowska L, Olivotto I, Limongelli G, Anastasakis A, Weintraub R, Biagini E, Ragni L, Prendiville T, Duignan S, McLeod K, Ilina M, Fernandez A, Bokenkamp R, Baban A, Kubus P, Daubeney PEF, Sarquella-Brugada G, Cesar S, Marrone C, Bhole V, Medrano C, Uzun O, Brown E, Gran F, Castro FJ, Stuart G, Vignati G, Barriales-Villa R, Guereta LG, Adwani S, Linter K, Bharucha T, Garcia-Pavia P, Rasmussen TB, Calcagnino MM, Jones CB, De Wilde H, Toru-Kubo J, Felice T, Mogensen J, Mathur S, Reinhardt Z, O'Mahony C, Elliott PM, Omar RZ, Kaski JP. Development of a Novel Risk Prediction Model for Sudden Cardiac Death in Childhood Hypertrophic Cardiomyopathy (HCM Risk-Kids). JAMA Cardiol 2019;4(9):918-927.

17. Miron A, Lafreniere-Roula M, Fan CS, Armstrong KR, Dragulescu A, Papaz T, Manlhiot C, Kaufman B, Butts RJ, Gardin L, Stephenson EA, Howard TS, Aziz PF, Balaji S, Beauséjour Ladouceur V, Benson LN, Colan SD, Godown J, Henderson HT, Ingles J, Jeewa A, Jefferies JL, Lal AK, Mathew J, Jean-St-Michel E, Michels M, Nakano SJ, Olivotto I, Parent JJ, Pereira AC, Semsarian C, Whitehill RD, Wittekind SG, Russell MW, Conway J, Richmond ME, Villa C, Weintraub RG, Rossano JW, Kantor PF, Ho CY, Mital S. A Validated Model for Sudden Cardiac Death Risk Prediction in Pediatric Hypertrophic Cardiomyopathy. Circulation 2020.

18. O'Mahony C, Jichi F, Ommen SR, Christiaans I, Arbustini E, Garcia-Pavia P, Cecchi F, Olivotto I, Kitaoka H, Gotsman I, Carr-White G, Mogensen J, Antoniades L, Mohiddin SA, Maurer MS, Tang HC, Geske JB, Siontis KC, Mahmoud KD, Vermeer A, Wilde A, Favalli V, Guttmann OP, Gallego-Delgado M, Dominguez F, Tanini I, Kubo T, Keren A, Bueser T, Waters S, Issa IF, Malcolmson J, Burns T, Sekhri N, Hoeger CW, Omar RZ, Elliott PM. International External Validation Study of the 2014 European Society of Cardiology Guidelines on Sudden Cardiac Death Prevention in Hypertrophic Cardiomyopathy (EVIDENCE-HCM). Circulation 2018;137(10):1015-1023. 
19. O'Mahony C, Jichi F, Pavlou M, Monserrat L, Anastasakis A, Rapezzi C, Biagini E, Gimeno JR, Limongelli G, McKenna WJ, Omar RZ, Elliott PM, Hypertrophic Cardiomyopathy Outcomes I. A novel clinical risk prediction model for sudden cardiac death in hypertrophic cardiomyopathy (HCM risk-SCD). Eur Heart J 2014;35(30):2010-20.

20. Ostman-Smith I, Wettrell G, Riesenfeld T. A cohort study of childhood hypertrophic cardiomyopathy: improved survival following high-dose beta-adrenoceptor antagonist treatment. J Am Coll Cardiol 1999;34(6):1813-22.

21. Kaski JP, Tome Esteban MT, Lowe M, Sporton S, Rees P, Deanfield JE, McKenna WJ, Elliott PM. Outcomes after implantable cardioverter-defibrillator treatment in children with hypertrophic cardiomyopathy. Heart 2007;93(3):372-4.

22. Maron BJ, Spirito P, Ackerman MJ, Casey SA, Semsarian C, Estes NA, 3rd, Shannon KM, Ashley EA, Day SM, Pacileo G, Formisano F, Devoto E, Anastasakis A, Bos JM, Woo A, Autore C, Pass RH, Boriani G, Garberich RF, Almquist AK, Russell MW, Boni L, Berger S, Maron MS, Link MS. Prevention of sudden cardiac death with implantable cardioverterdefibrillators in children and adolescents with hypertrophic cardiomyopathy. J Am Coll Cardiol 2013;61(14):1527-35.

23. Norrish G, Chubb H, Field E, McLeod K, llina M, Spentzou G, Till J, Daubeney PEF, Stuart AG, Matthews J, Hares D, Brown E, Linter K, Bhole V, Pillai K, Bowes M, Jones CB, Uzun O, Wong A, Yue A, Sadagopan S, Bharucha T, Yap N, Rosenthal E, Mathur S, Adwani S, Reinhardt Z, Mangat J, Kaski JP. Clinical outcomes and programming strategies of implantable cardioverter-defibrillator devices in paediatric hypertrophic cardiomyopathy: a UK National Cohort Study. Europace 2020.

24. Kamp AN, Von Bergen NH, Henrikson CA, Makhoul M, Saarel EV, Lapage MJ, Russell MW, Strieper M, Yu S, Dick M, Day SM, Bradley DJ. Implanted defibrillators in young hypertrophic cardiomyopathy patients: a multicenter study. Pediatr Cardiol 2013;34(7):1620-7.

25. Dechert BE, Bradley DJ, Serwer GA, Dick li M, Lapage MJ. Implantable Cardioverter Defibrillator Outcomes in Pediatric and Congenital Heart Disease: Time to System Revision. Pacing Clin Electrophysiol 2016;39(7):703-8.

26. O'Mahony C, Lambiase PD, Quarta G, Cardona M, Calcagnino M, Tsovolas K, AlShaikh S, Rahman SM, Arnous S, Jones S, McKenna W, Elliott P. The long-term survival and the risks and benefits of implantable cardioverter defibrillators in patients with hypertrophic cardiomyopathy. Heart 2012;98(2):116-25.

27. Ommen SR, Mital S, Burke MA, Day SM, Deswal A, Elliott P, Evanovich LL, Hung J, Joglar JA, Kantor P, Kimmelstiel C, Kittleson M, Link MS, Maron MS, Martinez MW, Miyake CY, Schaff HV, Semsarian C, Sorajja P. 2020 AHA/ACC Guideline for the Diagnosis and Treatment of Patients With Hypertrophic Cardiomyopathy: Executive Summary: A Report of the American College of Cardiology/American Heart Association Joint Committee on Clinical Practice Guidelines. Circulation 2020;142(25):e533-e557.

28. Norrish G, Cantarutti N, Pissaridou E, Ridout DA, Limongelli G, Elliott PM, Kaski JP. Risk factors for sudden cardiac death in childhood hypertrophic cardiomyopathy: A systematic review and meta-analysis. Eur J Prev Cardiol 2017:2047487317702519. 29. Norrish G, Ding T, Field E, McLeod K, Ilina M, Stuart G, Bhole V, Uzun O, Brown E, Daubeney PEF, Lota A, Linter K, Mathur S, Bharucha T, Kok KL, Adwani S, Jones CB, Reinhardt Z, Omar RZ, Kaski JP. A validation study of the European Society of Cardiology guidelines for risk stratification of sudden cardiac death in childhood hypertrophic cardiomyopathy.

Europace 2019;21(10):1559-1565. 
30. O'Mahony C, Jichi F, Ommen SR, Christiaans I, Arbustini E, Garcia-Pavia P, Cecchi F, Olivotto I, Kitaoka H, Gotsman I, Carr-White G, Mogensen J, Antoniades L, Mohiddin S, Maurer MS, Tang HC, Geske JB, Siontis KC, Mahmoud K, Vermeer A, Wilde A, Favalli V, Guttmann O, Gallego-Delgado M, Dominguez F, Tanini I, Kubo T, Keren A, Bueser T, Waters S, Issa IF, Malcolmson J, Burns T, Sekhri N, Hoeger CW, Omar RZ, Elliott PM. An International External Validation Study of the 2014 European Society of Cardiology Guideline on Sudden Cardiac Death Prevention in Hypertrophic Cardiomyopathy (Evidence from HCM). Circulation 2017.

31. Ostman-Smith I, Wettrell G, Keeton B, Holmgren D, Ergander U, Gould S, Bowker C, Verdicchio M. Age- and gender-specific mortality rates in childhood hypertrophic cardiomyopathy. Eur Heart J 2008;29(9):1160-7.

32. Weng Z, Yao J, Chan RH, He J, Yang X, Zhou Y, He Y. Prognostic Value of LGE-CMR in HCM: A Meta-Analysis. JACC Cardiovasc Imaging 2016;9(12):1392-1402.

33. Axelsson Raja A, Farhad H, Valente AM, Couce JP, Jefferies JL, Bundgaard H, Zahka K, Lever H, Murphy AM, Ashley E, Day SM, Sherrid MV, Shi L, Bluemke DA, Canter CE, Colan SD, Ho CY. Prevalence and Progression of Late Gadolinium Enhancement in Children and Adolescents with Hypertrophic Cardiomyopathy. Circulation 2018.

34. Windram JD, Benson LN, Dragelescu A, Yoo SJ, Mertens L, Wong D, GrosseWortmann L. Distribution of Hypertrophy and Late Gadolinium Enhancement in Children and Adolescents with Hypertrophic Cardiomyopathy. Congenit Heart Dis 2015;10(6):E25867.

35. Petryka-Mazurkiewicz J, Ziolkowska L, Kowalczyk-Domagala M, Mazurkiewicz L, Boruc A, Spiewak M, Misko J, Bieganowska K, Marczak M, Brzezinska-Rajszys G. LGE for Risk Stratification in Primary Prevention in Children With HCM. JACC Cardiovasc Imaging 2020.

36. Norrish G, Topriceanu C, Qu C, Field E, Walsh H, Ziolkowska L, Olivotto I, Passantino S, Favilli S, Anastasakis A, Vlagkouli V, Weintraub R, King I, Biagini E, Ragni L, Prendiville T, Duignan S, McLeod K, Ilina M, Fernandez A, Bokenkamp R, Baban A, Drago F, Kubus P, Daubeney PEF, Chivers S, Sarquella-Brugada G, Cesar S, Marrone C, Medrano C, Alvarez Garcia-Roves R, Uzun O, Gran F, Castro FJ, Gimeno JR, Barriales-Villa R, Rueda F, Adwani S, Searle J, Bharucha T, Siles A, Usano A, Rasmussen TB, Jones CB, Kubo T, Mogensen J, Reinhardt Z, Cervi E, Elliott PM, Omar RZ, Kaski JP. The role of the electrocardiographic phenotype in risk stratification for sudden cardiac death in childhood hypertrophic cardiomyopathy. Eur J Prev Cardiol 2021.

37. Harper AR, Goel A, Grace C, Thomson KL, Petersen SE, Xu X, Waring A, Ormondroyd E, Kramer CM, Ho CY, Neubauer S, Tadros R, Ware JS, Bezzina CR, Farrall M, Watkins H. Common genetic variants and modifiable risk factors underpin hypertrophic cardiomyopathy susceptibility and expressivity. Nat Genet 2021;53(2):135-142.

38. Calcagni G, Limongelli G, D'Ambrosio A, Gesualdo F, Digilio MC, Baban A, Albanese SB, Versacci P, De Luca E, Ferrero GB, Baldassarre G, Agnoletti G, Banaudi E, Marek J, Kaski JP, Tuo G, Russo MG, Pacileo G, Milanesi O, Messina D, Marasini M, Cairello F, Formigari R, Brighenti M, Dallapiccola B, Tartaglia M, Marino B. Cardiac defects, morbidity and mortality in patients affected by RASopathies. CARNET study results. Int J Cardiol 2017;245:92-98.

39. Maskatia SA, Decker JA, Spinner JA, Kim JJ, Price JF, Jefferies JL, Dreyer WJ, Smith EO, Rossano JW, Denfield SW. Restrictive physiology is associated with poor outcomes in children with hypertrophic cardiomyopathy. Pediatr Cardiol 2012;33(1):141-9.

40. Ziolkowska L, Turska-Kmiec A, Petryka J, Kawalec W. Predictors of Long-Term Outcome in Children with Hypertrophic Cardiomyopathy. Pediatr Cardiol 2016;37(3):448-58. 
41. Balaji S, DiLorenzo MP, Fish FA, Etheridge SP, Aziz PF, Russell MW, Tisma S, Pflaumer A, Sreeram N, Kubus P, Law IH, Kantoch MJ, Kertesz NJ, Strieper M, Erickson CC, Moore JP, Nakano SJ, Singh HR, Chang P, Cohen M, Fournier A, llina MV, Smith RT, Zimmerman F, Horndasch M, Li W, Batra A, Liberman L, Hamilton R, Janson CM, Sanatani S, Zeltser I, McDaniel G, Blaufox AD, Garnreiter JM, Katcoff $H$, Shah M. Risk factors for lethal arrhythmic events in children and adolescents with hypertrophic cardiomyopathy and an implantable defibrillator: An international multicenter study. Heart Rhythm 2019;16(10):1462-1467. 42. Alexander PMA, Nugent AW, Daubeney PEF, Lee KJ, Sleeper LA, Schuster T, Turner C, Davis AM, Semsarian C, Colan SD, Robertson T, Ramsay J, Justo R, Sholler GF, King I, Weintraub RG. Long-Term Outcomes of Hypertrophic Cardiomyopathy Diagnosed During Childhood: Results From a National Population-Based Study. Circulation 2018;138(1):29-36. 43. Ostman-Smith I, Wettrell G, Keeton B, Riesenfeld T, Holmgren D, Ergander U. Echocardiographic and electrocardiographic identification of those children with hypertrophic cardiomyopathy who should be considered at high-risk of dying suddenly. Cardiol Young 2005;15(6):632-42.

44. Ostman-Smith I, Sjoberg G, Rydberg A, Larsson P, Fernlund E. Predictors of risk for sudden death in childhood hypertrophic cardiomyopathy: the importance of the ECG risk score. Open Heart 2017;4(2):e000658.

45. Smith BM, Dorfman AL, Yu S, Russell MW, Agarwal PP, Mahani MG, Lu JC. Clinical significance of late gadolinium enhancement in patients<20 years of age with hypertrophic cardiomyopathy. Am J Cardiol 2014;113(7):1234-9.

46. Mathew J, Zahavich L, Lafreniere-Roula M, Wilson J, George K, Benson L, Bowdin S, Mital S. Utility of genetics for risk stratification in pediatric hypertrophic cardiomyopathy. Clin Genet 2018;93(2):310-319.

47. Maurizi N, Passantino S, Spaziani G, Girolami F, Arretini A, Targetti M, Pollini I, Tomberli A, Pradella S, Calabri GB, Vinattieri V, Bertaccini B, Leone O, De Simone L, Rapezzi C, Marchionni N, Cecchi F, Favilli S, Olivotto I. Long-term Outcomes of Pediatric-Onset Hypertrophic Cardiomyopathy and Age-Specific Risk Factors for Lethal Arrhythmic Events. JAMA Cardiol 2018;3(6):520-525. 
Table 1: Risk factors for sudden cardiac death in childhood HCM. Adapted from Norrish et $\mathrm{al}^{28}$

\begin{tabular}{|c|c|c|}
\hline & Clinical risk factor & Comment \\
\hline \multirow[t]{4}{*}{$\begin{array}{l}\text { Major risk } \\
\text { factors }\end{array}$} & Previous VF/VT & $\begin{array}{l}\text { Pooled HR 5.4 (95\% Cl 3.67-7.95, P value <0.001). } \\
\text { Pooled OR 5.06 ( } 95 \% \text { 2.11-12.17, P value <0.001) }\end{array}$ \\
\hline & $\begin{array}{l}\text { Unexplained } \\
\text { syncope }\end{array}$ & $\begin{array}{l}\text { Pooled HR } 1.89(0.69-5.16, p \text { value } 0.22) \text {. Pooled OR } \\
2.64(1.21-5.79, p \text { value } 0.02)\end{array}$ \\
\hline & NSVT & $\begin{array}{l}\text { Pooled HR } 2.13 \text { (95\% Cl 1.21-3.74, p value 0.0009). } \\
\text { Pooled OR } 2.05 \text { ( } 96 \% \text { Cl 0.98-4.28, p value 0.06). }\end{array}$ \\
\hline & Extreme LVH & $\begin{array}{l}\text { Pooled HR } 1.8(95 \% \mathrm{Cl} 0.75-4.32, \mathrm{p} \text { value } 0.19) \text {. } \\
\text { Pooled OR } 1.70 \text { ( } 95 \% \mathrm{Cl} 0.85-3.40, \mathrm{p} \text { value } 0.13) \text {. The } \\
\text { most useful measure of } \mathrm{LVH} \text { for risk stratification is } \\
\text { unknown. }\end{array}$ \\
\hline \multirow[t]{6}{*}{$\begin{array}{l}\text { Other } \\
\text { putative risk } \\
\text { factors }\end{array}$} & LA dilatation & $\begin{array}{l}\text { Left atrial size was not included as a major risk factor } \\
\text { in the meta-analysis but a significant association has } \\
\text { subsequently been reported in four studies }{ }^{16,17,39,40} \text {. }\end{array}$ \\
\hline & LVOT gradient & $\begin{array}{l}\text { The definition of LVOT obstruction varies in the } \\
\text { literature. Increasing LVOT gradient has been linked } \\
\text { to } \mathrm{SCD}^{40}{ }^{41} \text { and two large studies have described an } \\
\text { inverse relationship between LVOT gradient and risk } \\
\text { in childhood } \\
16,17 .\end{array}$ \\
\hline & $\begin{array}{l}\text { Family history of } \\
\text { SCD }\end{array}$ & $\begin{array}{l}\text { Only } 1 / 10 \text { studies reported a significant association } \\
\text { between a family history of SCD and SCD event }{ }^{24} \text {. } \\
\text { Limited evidence to support its use as a risk factor } \\
\text { during childhood. }\end{array}$ \\
\hline & Age & $\begin{array}{l}\text { The role of age in SCD is not fully understood. SCD } \\
\text { risk has been reported to be increased in pre- } \\
\text { adolescent years ( } 9-14 y r s)^{31} \text { and children presenting } \\
\text { in infancy are believed to be at lower risk } \\
7,42\end{array}$ \\
\hline & 12 lead ECG & $\begin{array}{l}\text { Proposed } 12 \text { lead ECG features include; measures of } \\
\text { LV hypertrophy }{ }^{43} \text { and abnormal repolarisation }{ }^{44} \text { but a } \\
\text { recent large study showed no association between } \\
\text { individual ECG parameters and risk }{ }^{36} \text {. An ECG risk } \\
\text { score has been developed by Ostman-Smith et al }{ }^{44} \\
\text { but this was shown to have only moderate } \\
\text { discriminatory ability in an external validation study }\end{array}$ \\
\hline & LGE on CMRI & $\begin{array}{l}\text { LGE has been shown to increase during childhood } \\
\text { and is associated with left ventricular hypertrophy }{ }^{33} \text {. } \\
\text { It is unclear if LGE is an independent risk factor for } \\
\mathrm{SCD}^{34,45} \text {. }\end{array}$ \\
\hline
\end{tabular}



not fully understood. In small cohorts, the presence of a pathogenic sarcomeric mutation has been described to be associated with worse prognosis ${ }^{46}$ and certain genotypes associated with higher arrhythmic risk ${ }^{47}$. 
Table 2: Comparison between HCM Risk-Kids and PRIMaCY risk prediction models for sudden cardiac death in childhood hypertrophic cardiomyopathy

HCM Risk-Kids

$\mathrm{n}$ (development and internal validation)

\section{Risk factors}

$\mathrm{LVH}$

$$
\checkmark(\text { MLVWT z- }
$$$$
\text { score) }
$$

$\checkmark$ (IVS and LVPW

z-scores)

LA z-score

Unexplained syncope

NSVT

LVOT gradient

Age at diagnosis

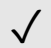

$\checkmark$

$\checkmark$

$\checkmark$

$\times$
PRIMaCY

572

\section{Model performance}

$\begin{array}{lcc}\begin{array}{l}\text { Internal validation C- } \\ \text { statistic }\end{array} & 0.69(0.66-0.72) & 0.75 \text { (CI not } \\ \text { provided) }\end{array}$

LVH - left ventricular hypertrophy; MLVWT - maximal left ventricular wall thickness; IVS interventricular septum; LVPW - left ventricular posterior wall; LA - left atrium; NSVT nonsustained ventricular tachycardia; LVOT - left ventricular outflow tract 
Figure 1: Performance of HCM Risk-Kids model A) Kaplan Meier curve showing cumulative probability of meeting SCD end point within 5 years by estimated clinical risk group $b$ ) Comparison of observed and predicted risk by clinical risk group. Reproduced with permission from Norrish et al. ${ }^{16}$

A Probability of end points at $5 y$

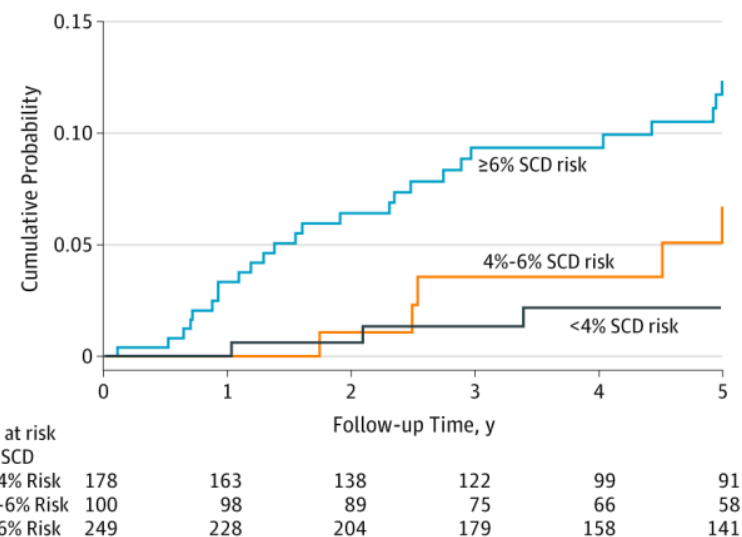

B Observed vs predicted risk at $5 \mathrm{y}$

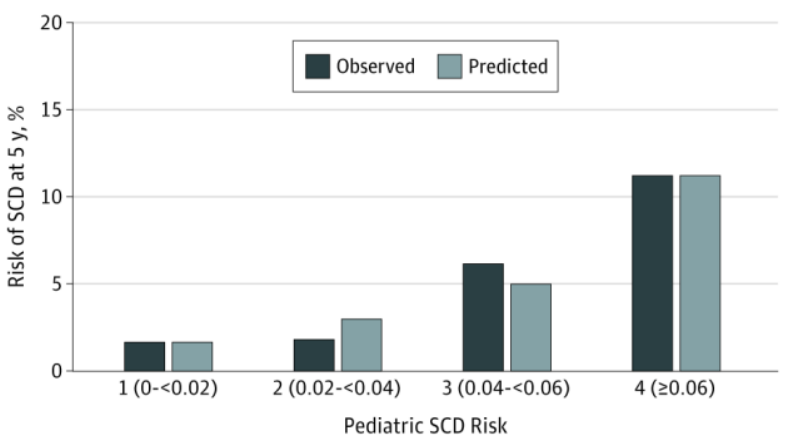

